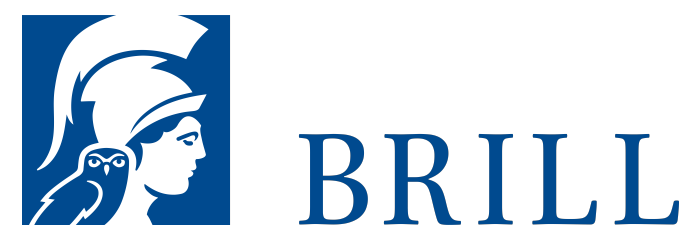

\title{
Viele falsche Hoffnungen
}

Judenverfolgung in den Niederlanden 1940-1945

Author: Katja Happe

Zwischen 1940 und 1945 kamen drei Viertel der

niederländischen Juden im Holocaust um - ein höherer Anteil als in allen anderen Ländern Nord- und Westeuropas. Der vorliegende Band ist die erste Darstellung der Judenverfolgung in den Niederlanden auf Deutsch. Dabei richtet die Autorin ein besonderes Augenmerk auf die ausländischen Hilfsbemühungen zur Rettung der Juden in den Niederlanden. Denn die entsprechenden Aktivitäten der niederländischen Exilregierung und ausländischer Hilfsorganisationen sind bislang kaum näher untersucht worden. Darüber hinaus erörtert Katja Happe das Vorgehen der deutschen Täter, schildert die fortschreitende Entrechtung und Isolation der Juden in den Niederlanden sowie die Bemühungen des Jüdischen Rats und derJuden, den Deportationen zu entgehen. Zudem durchleuchtet die Autorin anschaulich die vielfältigen Reaktionen der niederländischen Öffentlichkeit auf die Verfolgungen - ein bis heute in den Niederlanden viel diskutiertes Thema, über das in Deutschland kaum etwas bekannt ist.

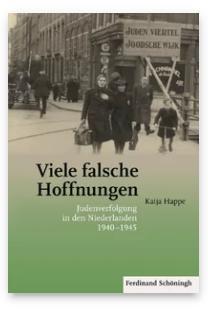

Pages: 365

Seiten

Language:

German

Subjects:

Modern History,

History

Publisher: Brill |

Schöningh

E-Book (PDF)

Released online:

23 Oct 2017

ISBN: 978-3-

657-78424-0

List price

Hardback

Publication date: 2o Oct 2017

ISBN: $978-3-$ 506-78424-7

List price 
Katja Happe arbeitete bis 2015 am Germanischen Nationalmuseum, Nürnberg, als wiss. Mitarbeiterin bei verschiedenen Projekten zur Geschichte der Judenverfolgung sowie bei der Gedenkstätte Münchner Platz, Dresden. Seit 2016 ist sie Beraterin im History Marketing.

For more information see brill.com

Order information: Order online at brill.com +44330 3330049 | customerservices@brill.com Submission information: brill.com/authors

Titles published by Brill | Fink, Brill | mentis or Brill | Schöningh: +49(o)71 5413279216 | brill@brocom.de 